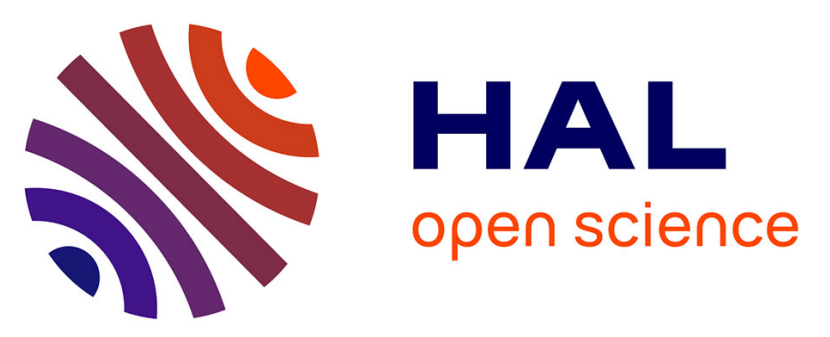

\title{
Unconventional immune-related phenomena observed using 18F-FDG PET/CT in Hodgkin lymphoma treated with anti PD-1 monoclonal antibodies
}

Laurent Dercle, Fatima-Zohra Mokrane, Jean Marc Schiano de Colella, Apasia Stamatoullas, Franck Morschhauser, Pauline Brice, Hervé Ghesquières, Olivier Casasnovas, Aiping Chen, Guillaume Manson, et al.

\section{To cite this version:}

Laurent Dercle, Fatima-Zohra Mokrane, Jean Marc Schiano de Colella, Apasia Stamatoullas, Franck Morschhauser, et al.. Unconventional immune-related phenomena observed using 18F-FDG PET/CT in Hodgkin lymphoma treated with anti PD-1 monoclonal antibodies. European Journal of Nuclear Medicine and Molecular Imaging, 2019, 46 (6), pp.1391-1392. 10.1007/s00259-019-04310-x . hal02119287

\section{HAL Id: hal-02119287}

\section{https://hal-univ-rennes1.archives-ouvertes.fr/hal-02119287}

Submitted on 14 Jun 2019

HAL is a multi-disciplinary open access archive for the deposit and dissemination of scientific research documents, whether they are published or not. The documents may come from teaching and research institutions in France or abroad, or from public or private research centers.
L'archive ouverte pluridisciplinaire HAL, est destinée au dépôt et à la diffusion de documents scientifiques de niveau recherche, publiés ou non, émanant des établissements d'enseignement et de recherche français ou étrangers, des laboratoires publics ou privés. 
TITLE

Unconventional immune-related phenomena observed using 18F-FDG PET/CT in Hodgkin Lymphoma treated with anti PD-1 monoclonal antibodies

\section{AUTHORS}

Laurent Dercle ${ }^{1,2^{*}}$, Fatima-Zohra Mokrane ${ }^{1,3^{*}}$, JM Schiano de Colella ${ }^{4}$, Apasia Stamatoullas ${ }^{5}$, Franck Morschhauser ${ }^{6}$, Pauline Brice ${ }^{7}$, Hervé Ghesquières ${ }^{8}$, Olivier Casasnovas ${ }^{9}$, Aiping Chen ${ }^{10}$, Guillaume Manson ${ }^{11,12}$, Roch Houot ${ }^{11,12}$

1. Department of Radiology, New York Presbyterian Hospital, Columbia University Medical Center, New York, NY, 10039, USA.

2. UMR1015, Institut Gustave Roussy, 94800, Université Paris Saclay, Villejuif, France.

3. Radiology department. Rangueil University Hospital. 1 Avenue du Professeur Jean Poulhes, 31059 , Toulouse, France.

4. Department of Hematology, Paoli-Calmette Institute, Marseille, France

5. Department of Hematology, Centre Henri Becquerel, Rouen, France

6. Univ. Lille, CHU Lille, EA 7365 - GRITA - Groupe de Recherche sur les formes Injectables et les Technologies Associées, F-59000 Lille, France

7. Department of Hematology, Saint-Louis Hospital, AP-HP, Paris, France

8. Department of Hematology, University Hospital of Lyon, Lyon, France

9. Department of Hematology, University Hospital of Dijon, Dijon, France

10. Department of Radiology, First Affiliated Hospital of NanJing Medical University, No.300 GuangZhou Road, 210029, Nanjing, China

11. Department of Hematology, University Hospital of Rennes, Rennes, France

12. INSERM, U1236, Rennes, France

\section{*Contributed equally}

\section{CORRESPONDENCE}

Dr. Laurent Dercle

New York Presbyterian Hospital, Columbia University Medical Center, New York, USA.

Gustave Roussy, INSERM, U1015, France

(laurent.dercle@gmail.com)

Tel: 1-626-780-3562 Fax:

\section{KEYWORDS}

Nivolumab; pembrolizumab; anti PD-1; 18F-FDG PET; PET/CT; computed tomography; Hodgkin lymphoma.

\section{ACKNOWLEDGMENTS}

Sincere appreciation is expressed to The Lymphoma Academic Research Organisation, Samy Ammari, Benoit Bareau, Florence Broussais, Barbara Burroni, Fanny Cherblanc, Sophie Ducastelle, Marjan Ertault, Luc-Mathieu Fornecker, Laure Flament, Georges Garnier, Thomas Gastine, Elodie Gat, Stéphanie Guidez, Katell Le Dû, Fabien Lebras, Sophie Lefort, Elena Loppinet, Jean Pierre Marolleau, Nadine Morineau, Frédéric Peyrade, Caroline Regny, Isabelle RocheLachaise, Lawrence H. Schwartz, Mohamed Touati. L Dercle work was funded by a grant from Fondation Philanthropia, Geneva, Switzerland and the Fondation Nuovo-Soldati. 


\section{CONFLICT OF INTEREST}

R.H.: consulting fees and/or honoraria from Bristol-Myers Squibb

F.M.: adboard from Bristol-Myers Squibb. Honoraria for adboard and scientific lectures: Roche, Celgene, Servier, Gilead, Janssen

Other authors declare no competing financial interests. 


\section{TEXT}

The paradigm of response in Hodgkin lymphoma (HL) was developed in cytotoxic chemotherapies and its use as a reference model for immune-modulatory regimens, which restores the immune system's anti-tumor capacity, is questioned $[1,2]$. In a centralized review, we retrospectively analyzed 60 consecutive patients from 34 participating institutions with relapsed or refractory $(\mathrm{R} / \mathrm{R}) \mathrm{HL}$ treated with nivolumab after institutional review board approval. We observed unconventional immune-related phenomena regarding tumor response or progression, and adverse events (irAE). Transient progression in lesions size and metabolism, while the patients were continuing Nivolumab, were observed in $3.3 \%$ of patients at 3 months $(\mathbf{A}, \mathbf{B})$. Nonetheless, while pseudo-progression represents the most described immune-related pattern of response in solid tumors, along with abscopal effect and hyperprogression [3, 4], these early pseudo-progressive lesions did not significantly alter response evaluation since they were all observed in unequivocally progressive patients. The most significant encountered problems were mixed responses $(\mathbf{B})$ and irAEs (A, C). Medical imaging detects $74 \%$ of irAE [5] in solid tumors, which can occur theoretically at any site and at any time. The most frequent sites reported in solid tumors are lung, mediastinal lymph nodes (sarcoidosis-like), enterocolitis, hypophysitis, thyroiditis, hepatitis, arthritis, and pancreatitis. While we identified such irAE in our cohort, we also identified imaging findings suggestive of gastritis and hemolytic anemia (A, C). In clinical routine, these immune-related phenomena should be considered as potential differential diagnoses (e.g., an increased spleen metabolism can be observed in true progression, spleen activation reflecting treatment efficacy [4], and iRAE).

\section{REFERENCES}

[1] E. Lopci, M. Meignan, Deauville score: the Phoenix rising from ashes, Eur J Nucl Med Mol Imaging (2018).

[2] N. Aide, R.J. Hicks, C. Le Tourneau, S. Lheureux, S. Fanti, E. Lopci, FDG PET/CT for assessing tumour response to immunotherapy, European journal of nuclear medicine and molecular imaging (2019) 1-13 1619-7070.

[3] L. Dercle, S. Ammari, R.D. Seban, L.H. Schwartz, R. Houot, N. Labaied, F.Z. Mokrane, J. Lazarovici, A. Danu, A. Marabelle, V. Ribrag, J.M. Michot, Kinetics and nadir of responses to immune checkpoint blockade by anti-PD1 in patients with classical Hodgkin lymphoma, Eur J Cancer 91 (2018) 136-144. [4] L. Dercle, R.D. Seban, J. Lazarovici, L.H. Schwartz, R. Houot, S. Ammari, A. Danu, V. Edeline, A. Marabelle, V. Ribrag, J.M. Michot, (18)F-FDG PET and CT Scans Detect New Imaging Patterns of Response and Progression in Patients with Hodgkin Lymphoma Treated by Anti-Programmed Death 1 Immune Checkpoint Inhibitor, J Nucl Med 59(1) (2018) 15-24.

[5] A. Mekki, L. Dercle, P. Lichtenstein, A. Marabelle, J.-M. Michot, O. Lambotte, J. Le Pavec, E. De Martin, C. Balleyguier, S. Champiat, Detection of immune-related adverse events by medical imaging in patients treated with anti-programmed cell death 1, European Journal of Cancer 96 (2018) 91-104. 


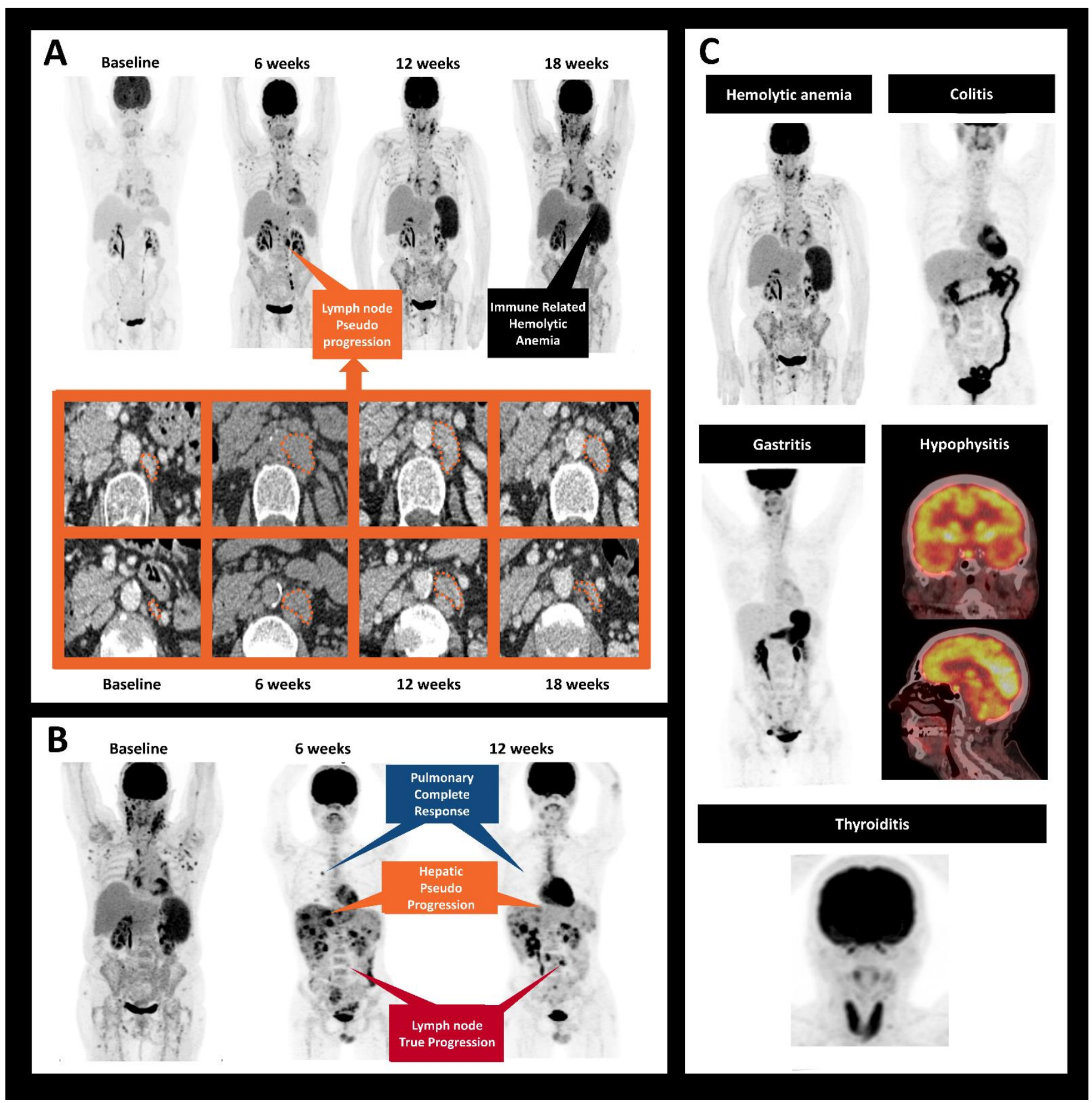

